\title{
In vitro activities of ceftobiprole and doripenem tested against frequently encountered aerobic and facultative Gram-positive and Gram-negative bacterial pathogens isolated from patients in Canadian hospitals in 2007
}

\author{
James A Karlowsky PhD, Mel DeCorby MSc, Daryl J Hoban PhD, George G Zhanel PhD
}

\begin{abstract}
JA Karlowsky, M DeCorby, DJ Hoban, GG Zhanel. In vitro activities of ceftobiprole and doripenem tested against frequently encountered aerobic and facultative Gram-positive and Gram-negative bacterial pathogens isolated from patients in Canadian hospitals in 2007. Can J Infect Dis Med Microbiol 2009;20(Suppl A):59A-66A.
\end{abstract}

BACKGROUND: In 2008, ceftobiprole was approved by Health Canada for the treatment of patients with complicated skin and skin structure infections including diabetic foot infections; approval of ceftobiprole by the United States Food and Drug Administration is pending. Doripenem is currently under review by Health Canada and was approved by the United States Food and Drug Administration in 2007 for the treatment of patients with complicated intra-abdominal infections and complicated urinary tract infections, including pyelonephritis.

OBJECTIVES: To determine the in vitro activities of ceftobiprole and doripenem using a collection of frequently isolated aerobic and facultative bacteria cultured from patient blood, urine, respiratory and wound specimens in 12 Canadian hospitals in 2007.

METHODS: Isolates were tested for their susceptibility to a panel of antimicrobial agents using the Clinical and Laboratory Standards Institute broth microdilution method.

RESULTS: Ceftobiprole inhibited all isolates of methicillin-resistant Staphylococcus aureus $(\mathrm{n}=385)$, methicillin-resistant Staphylococcus epidermidis $(\mathrm{n}=20)$, methicillin-susceptible $S$ aureus $(\mathrm{n}=1095)$ and methicillin-susceptible $S$ epidermidis $(n=108)$ at a minimum inhibitory concentration (MIC) of $2 \mu \mathrm{g} / \mathrm{mL}$ or less; all isolates of Streptococcus pyogenes $(\mathrm{n}=105)$ were inhibited by ceftobiprole at $0.06 \mu \mathrm{g} / \mathrm{mL}$ or less. All isolates of S aureus (MIC $4 \mu \mathrm{g} / \mathrm{mL}$ or less) and $S$ pyogenes (MIC $0.5 \mu \mathrm{g} / \mathrm{mL}$ or less) tested were susceptible to ceftobiprole. Greater than $99 \%$ of extended-spectrum beta-lactamase (ESBL)-negative Escherichia coli $(\mathrm{n}=1528)$ and Klebsiella pneumoniae $(\mathrm{n}=436)$ were susceptible to ceftobiprole (MIC $1 \mu \mathrm{g} / \mathrm{mL}$ or less); against other genera/species of Enterobacteriaceae, susceptibility to ceftobiprole ranged from $80.7 \%$ for Enterobacter cloacae ( $\mathrm{n}=166)$ to $99.2 \%$ for Proteus mirabilis $(\mathrm{n}=119)$. Ceftobiprole was less active against Pseudomonas aeruginosa $(n=633)$ ( $90 \%$ of isolates inhibited at a concentration of $32 \mu \mathrm{g} / \mathrm{mL}\left[\mathrm{MIC}_{90}\right]$ ) than Enterobacteriaceae. Doripenem inhibited $90 \%$ of isolates of $E$ coli $(\mathrm{n}=1577)$ and K pneumoniae $(\mathrm{n}=456)$, including ESBL-producing isolates $(\mathrm{n}=69)$, and E cloacae at a concentration of $0.06 \mu \mathrm{g} / \mathrm{mL}$ or less; doripenem and meropenem had $\mathrm{MIC}_{90} \mathrm{~s}$ of $8 \mu \mathrm{g} / \mathrm{mL}$ for the isolates of $P$ aeruginosa tested. Doripenem demonstrated in vitro activity indistinguishable from that of meropenem against Gram-positive pathogens. CONCLUSIONS: All isolates of methicillin-resistant $S$ aureus tested were susceptible to ceftobiprole (MIC $4 \mu \mathrm{g} / \mathrm{mL}$ or less), differentiating it from any other currently marketed beta-lactam. Doripenem demonstrated potent activity $\left(\mathrm{MIC}_{90} 0.5 \mu \mathrm{g} / \mathrm{mL}\right.$ or less) against all isolates of Enterobacteriaceae tested, including ESBL-producing $E$ coli and $\mathrm{K}$ pneumoniae, and as potent activity as meropenem $\left(\mathrm{MIC}_{90} 8 \mu \mathrm{g} / \mathrm{mL}\right)$ against $P$ aeruginosa. The current study demonstrated both ceftobiprole and doripenem to be promising broad-spectrum antibacterial agents.

Key Words: Bacteria; Ceftobiprole; Doripenem; Gram-negative; Grampositive

Les activités in vitro du ceftobiprole et du doripénem évaluées contre des pathogènes bactériens gram positifs et gram négatifs aérobiques et facultatifs fréquents, isolés chez des patients d'hôpitaux canadiens en 2007

HISTORIQUE : En 2008, Santé Canada a approuvé le ceftobiprole pour le traitement des patients atteints d'infections complexes de la peau et de la structure cutanée, y compris les infections du pied chez les diabétiques. Son approbation par la Food and Drug Administration des États-Unis est en instance. Santé Canada est à évaluer le doripénem, qui a été approuvé par la Food and Drug Administration des États-Unis en 2007 pour le traitement des patients atteints d'infections intraabdominales et d'infections urinaires complexes, y compris la pyélonéphrite.

OBJECTIFS : Déterminer les activités in vitro du ceftobiprole et du doripénem au moyen d'un ensemble de bactéries aérobiques et facultatives souvent isolées, cultivées dans des échantillons sanguins, urinaires, respiratoires et de plaies de 12 hôpitaux canadiens en 2007.

MÉTHODOLOGIE : Les isolats ont été vérifiés pour leur susceptibilité à un groupe d'antimicrobiens au moyen de la méthode de microdilution en milieu liquide du Clinical and Laboratory Standards Institute.

RÉSULTATS : Le ceftobiprole a inhibé tous les isolats de Staphylococcus aureus méthicillinorésistant $(\mathrm{n}=385)$, de Staphylococcus epidermidis méthicillinorésistant $(\mathrm{n}=20)$, de $S$ aureus susceptible à la méthicilline $(\mathrm{n}=1095)$ et de $S$ epidermidis susceptible à la méthicilline $(\mathrm{n}=108)$, à une concentration minimale inhibitrice [CMI] de $2 \mu \mathrm{g} / \mathrm{mL}$ ou moins. Tous les isolats de Streptococcus pyogenes $(\mathrm{n}=105)$ étaient inhibés par le ceftobiprole à $0,06 \mu \mathrm{g} / \mathrm{mL}$ ou moins. Tous les isolats de $S$ aureus (CMI de $4 \mu \mathrm{g} / \mathrm{mL}$ ou moins) et de $S$ pyogenes (CMI de $0,5 \mu \mathrm{g} / \mathrm{mL}$ ou moins) vérifiés étaient susceptibles au ceftobiprole. Plus de $99 \%$ des échantillons d'Escherichia coli $(\mathrm{n}=1528)$ et de Klebsiella pneumoniae $(\mathrm{n}=426)$ négatifs à la bêta-lactamase

suite page suivante

Department of Medical Microbiology, Faculty of Medicine, University of Manitoba, Winnipeg, Manitoba

Correspondence: Dr James A Karlowsky, Department of Clinical Microbiology, Health Sciences Centre, MS673C-820 Sherbrook Street,

Winnipeg, Manitoba R3A 1R9. Telephone 204-787-4597, fax 204-787-4699, e-mail jkarlowsky@hsc.mb.ca 
à large spectre (ESBL) étaient susceptibles au ceftobiprole (CMI de $1 \mu \mathrm{g} / \mathrm{mL}$ ou moins). Contre d'autres genres ou espèces d'entérobactériacées, la susceptibilité au ceftobripole variait entre $80,7 \%$ pour l'Enterobacter cloacae ( $\mathrm{n}=166)$ et $99,2 \%$ pour le Proteus mirabilis $(\mathrm{n}=119)$. Le ceftobiprole était moins actif contre le Pseudomonas aeruginosa ( $\mathrm{n}=633)(90 \%$ des isolats étaient inhibés à une concentration de $\left.32 \mu \mathrm{g} / \mathrm{mL}\left[\mathrm{CMI}_{90}\right]\right)$ que contre les entérobactériacées. Le doripénem inhibait $90 \%$ des isolats d'E coli $(n=1577)$ et de $K$ pneumoniae $(n=456)$, y compris les isolats producteurs d'ESBL $(n=69)$, ainsi que d'E cloacae à une concentration de $0,06 \mu \mathrm{g} / \mathrm{mL}$ ou moins. Le doripénem et le méropénem avaient une $\mathrm{CMI}_{90}$ de $8 \mu \mathrm{g} / \mathrm{mL}$ pour les isolats de $P$ aeruginosa vérifiés. Le doripénem a démontré une activité in vitro impossible à distinguer de celle du méropénem contre les pathogènes gram positifs.

CONCLUSIONS : Tous les isolats du $S$ aureus méthicillinorésistants vérifiés étaient susceptibles au ceftobiprole (CMI de $4 \mu \mathrm{g} / \mathrm{mL}$ ou moins), ce qui distingue cet agent de toutes les autres bêta-lactamines sur le marché. Le doripénem démontre une puissante activité $\left(\mathrm{CMI}_{90}\right.$ de $0,5 \mu \mathrm{g} / \mathrm{mL}$ ou moins) contre tous les isolats d'entérobactériacées y compris l'E coli et le $K$ pneumoniae producteurs d'ESBL, et une activité aussi puissante que le méropénem $\left(\mathrm{CMI}_{90}\right.$ de $\left.8 \mu \mathrm{g} / \mathrm{mL}\right)$ contre le de $P$ aeruginosa. La présente étude démontre que le ceftobripole et le doripénem sont tous deux des antimicrobiens à large spectre prometteurs.
$\mathrm{C}$ eftobiprole and doripenem are new broad-spectrum agents available, or soon to be available, to physicians in North America. In 2008, ceftobiprole was approved by Health Canada for the treatment of patients with complicated skin and skin structure infections including non-limb-threatening diabetic foot infections without concomitant osteomyelitis; approval of ceftobiprole by the United States Food and Drug Administration is pending for complicated skin and skin structure infections and nosocomial pneumonia. Doripenem is currently under review by Health Canada and was approved by the United States Food and Drug Administration in 2007 for the treatment of patients with complicated intra-abdominal infections and complicated urinary tract infections, including pyelonephritis.

Complicated skin and skin structure infections are a common occurrence in both outpatient and inpatient settings, with Staphylococcus aureus being the most frequent pathogen (1). Streptococcus pyogenes is also an important pathogen causing skin and skin structure infections as are Gram-negative bacilli, particularly Pseudomonas aeruginosa and Escherichia coli, and anaerobic bacteria for more complicated infections, including diabetic foot infections, where the etiology is frequently polymicrobial $(2,3)$. Important to the treatment of skin and skin structure infections is the observation that the prevalence of methicillin-resistant $S$ aureus (MRSA) is increasing. The SENTRY antimicrobial surveillance program reported an increase in methicillin resistance among North American clinical isolates of S aureus from $26.2 \%$ in 1998 to $47.4 \%$ in 2004 (3); other investigators showed that $50 \%$ of $S$ aureus causing skin and skin structure infections were MRSA (4). Another therapeutic consideration is that many recent anti-MRSA agents with clinical indications for the treatment of skin and skin structure infections (eg, linezolid, daptomycin) have activity only against Gram-positive pathogens, making singleagent therapy incomplete for those infections harbouring Gram-negative bacteria. Hence, the broad-spectrum activity of agents such as ceftobiprole with anti-MRSA activity may allow for the use of monotherapy in situations where a combination of antibacterials may otherwise be required.

Similarly, polymicrobial infections and emerging antimicrobial resistance among many Gram-positive and Gramnegative pathogens causing intra-abdominal and complicated urinary tract infections, support the development and strategic use of broad-spectrum agents including carbapenems. Doripenem is a new carbapenem that demonstrates the favourable characteristics of other carbapenems including broadspectrum activity and beta-lactamase stability $(5,6)$; it has in vitro activity against Gram-positive and Gram-negative human pathogens including anaerobic bacteria (5-7). Doripenem has potency against Gram-positive cocci that is most similar to that of imipenem, and an activity against Gram-negative bacteria that is most like that of meropenem (ie, two- to fourfold greater than that of imipenem) (6).

The objective of the current study was to determine the in vitro activities of ceftobiprole and doripenem using a recent collection of the most frequently isolated aerobic and facultative bacteria cultured from patient specimens by clinical microbiology laboratories in Canadian hospitals.

\section{Bacterial isolates}

\section{METHODS}

Isolates were collected and tested as part of the Canadian Ward Surveillance Study (CANWARD 2007). Details regarding isolate management are provided by Zhanel et al (8) in an earlier paper in the present supplement. Testing results are provided for genera/species with 20 or more isolates; this included 2703 Gram-positive isolates and $3726 \mathrm{Gram}$-negative isolates accounting for $81.6 \%$ of the total of 7881 isolates collected by the CANWARD 2007 study.

\section{Antimicrobial susceptibility testing}

Antimicrobial susceptibility testing was performed using the Clinical and Laboratory Standards Institute (CLSI) broth microdilution method (9). Minimum inhibitory concentrations (MICs) were interpreted according to CLSI breakpoints where available $(10,11)$. Breakpoints approved by Health Canada are published and were used to interpret ceftobiprole MICs for S aureus, Streptococcus species other than Streptococcus pneumoniae, and Enterobacteriaceae (12). Isolates of MRSA and extended-spectrum beta-lactamase (ESBL)-producing E coli and Klebsiella species were screened for and confirmed using the methods recommended by CLSI (10) and by molecular methods as previously described (8).

\section{RESULTS}

Ceftobiprole inhibited all isolates of MRSA, methicillinresistant Staphylococcus epidermidis (MRSE), methicillinsusceptible $S$ aureus, and methicillin-susceptible $S$ epidermidis at a concentration of $2 \mu \mathrm{g} / \mathrm{mL}$ or less (Table 1). Ceftobiprole MICs required to inhibit the growth of $90 \%$ of organisms $\left(\mathrm{MIC}_{90} \mathrm{~s}\right)$ were lower for methicillin-susceptible $S$ aureus $(0.5 \mu \mathrm{g} / \mathrm{mL})$ than for MRSA $(2 \mu \mathrm{g} / \mathrm{mL})$, and for methicillin-susceptible $S$ epidermidis $(0.5 \mu \mathrm{g} / \mathrm{mL})$ than for MRSE $(2 \mu \mathrm{g} / \mathrm{mL})$. All isolates of $S$ aureus tested, including MRSA, were susceptible to ceftobiprole (MIC $4 \mu \mathrm{g} / \mathrm{mL}$ or less). Ceftobiprole inhibited all isolates of beta-hemolytic streptococci (S pyogenes, Streptococcus agalactiae) and $S$ pneumoniae at concentrations of $0.06 \mu \mathrm{g} / \mathrm{mL}$ or less and $0.5 \mu \mathrm{g} / \mathrm{mL}$, respectively. All isolates of beta-hemolytic 
TABLE 1

Ceftobiprole and doripenem in vitro activity against 2703 aerobic Gram-positive bacteria isolated from patients in Canadian hospitals in 2007

\begin{tabular}{|c|c|c|c|c|c|}
\hline Organism and phenotype (isolates, $\mathrm{n}$ ) & Antimicrobial agent & MIC range, $\mu \mathrm{g} / \mathrm{mL}$ & $\mathrm{MIC}_{50}, \mu \mathrm{g} / \mathrm{mL}$ & $\mathrm{MIC}_{90}, \mu \mathrm{g} / \mathrm{mL}$ & $\%$ Susceptible \\
\hline Methicillin-susceptible & Cefazolin & $\leq 0.5-2$ & $\leq 0.5$ & 1 & 100 \\
\hline \multirow[t]{5}{*}{ Staphylococcus aureus (1095) } & Cefepime & $\leq 1-8$ & 4 & 8 & 100 \\
\hline & Ceftobiprole & $0.12-2$ & 0.25 & 0.5 & $100^{*}$ \\
\hline & Doripenem & $\leq 0.06-0.5$ & $\leq 0.06$ & 0.12 & NA \\
\hline & Ertapenem & $0.12-0.5$ & 0.25 & 0.25 & 100 \\
\hline & Meropenem & $\leq 0.06-1$ & $\leq 0.06$ & 0.12 & 100 \\
\hline & Cefepime & $32->256$ & $>256$ & $>256$ & 0 \\
\hline & Ceftobiprole & $0.25-2$ & 1 & 2 & 100 \\
\hline & Ceftriaxone & $>256$ & $>256$ & $>256$ & 0 \\
\hline & Doripenem & $\leq 0.06-64$ & 4 & 32 & NA \\
\hline & Ertapenem & $8->32$ & 8 & $>32$ & 0 \\
\hline & Meropenem & $16->32$ & 16 & $>32$ & 0 \\
\hline \multirow{3}{*}{ Staphylococcus epidermidis (108) } & Doripenem & $\leq 0.06-4$ & 0.5 & 4 & NA \\
\hline & Ertapenem & $0.12-2$ & 0.5 & 8 & 100 \\
\hline & Meropenem & $\leq 0.06-4$ & 1 & 4 & 100 \\
\hline \multirow[t]{7}{*}{ Methicillin-resistant S epidermidis (20) } & Cefazolin & $32-128$ & 64 & 128 & 0 \\
\hline & Cefepime & $32-128$ & 64 & 128 & 0 \\
\hline & Ceftobiprole & $\leq 1-2$ & 1 & 2 & NA \\
\hline & Ceftriaxone & $64->256$ & 256 & $>256$ & 0 \\
\hline & Doripenem & $16-32$ & 16 & 32 & NA \\
\hline & Ertapenem & $16->32$ & $>32$ & $>32$ & 0 \\
\hline & Meropenem & $16->32$ & 32 & $>32$ & 0 \\
\hline Penicillin-susceptible $^{\dagger}$ & Cefuroxime & $\leq 0.25-0.5$ & $\leq 0.25$ & $\leq 0.25$ & 100 \\
\hline \multirow{4}{*}{ Penicillin-intermediate ${ }^{\ddagger}$ S pneumoniae (103) } & Ceftriaxone & $\leq 0.06-0.5$ & $\leq 0.06$ & 0.25 & 100 \\
\hline & Doripenem & $\leq 0.06-0.25$ & $\leq 0.06$ & 0.12 & NA \\
\hline & Ertapenem & $\leq 0.06-0.25$ & $\leq 0.06$ & 0.25 & 100 \\
\hline & Meropenem & $\leq 0.06-0.25$ & $\leq 0.06$ & 0.12 & 100 \\
\hline \multirow[t]{6}{*}{ Penicillin-resistant ${ }^{\S} S$ pneumoniae (34) } & Cefuroxime & $1->16$ & 2 & 4 & 20.6 \\
\hline & Ceftobiprole & $\leq 0.06-0.5$ & 0.25 & 0.5 & NA \\
\hline & Ceftriaxone & $0.25-4$ & 0.5 & 1 & 94.1 \\
\hline & Doripenem & $\leq 0.06-2$ & 0.5 & 1 & NA \\
\hline & Ertapenem & $\leq 0.06-2$ & 0.5 & 1 & 97.1 \\
\hline & Meropenem & $\leq 0.06-2$ & 0.5 & 0.5 & 44.1 \\
\hline \multirow[t]{6}{*}{ Streptococcus pyogenes (105) } & Cefuroxime & $\leq 0.25$ & $\leq 0.25$ & $\leq 0.25$ & NA \\
\hline & Ceftobiprole & $\leq 0.06$ & $\leq 0.06$ & $\leq 0.06$ & 100 \\
\hline & Ceftriaxone & $\leq 0.06$ & $\leq 0.06$ & $\leq 0.06$ & 100 \\
\hline & Doripenem & $\leq 0.06$ & $\leq 0.06$ & $\leq 0.06$ & NA \\
\hline & Ertapenem & $\leq 0.06$ & $\leq 0.06$ & $\leq 0.06$ & 100 \\
\hline & Meropenem & $\leq 0.06$ & $\leq 0.06$ & $\leq 0.06$ & 100 \\
\hline \multirow[t]{6}{*}{ Streptococcus agalactiae (116) } & Cefuroxime & $\leq 0.25-0.5$ & $\leq 0.25$ & $\leq 0.25$ & NA \\
\hline & Ceftobiprole & $\leq 0.06$ & $\leq 0.06$ & $\leq 0.06$ & 100 \\
\hline & Ceftriaxone & $\leq 0.06-0.25$ & $\leq 0.06$ & $\leq 0.06$ & 100 \\
\hline & Doripenem & $\leq 0.06$ & $\leq 0.06$ & $\leq 0.06$ & NA \\
\hline & Ertapenem & $\leq 0.06$ & $\leq 0.06$ & $\leq 0.06$ & 100 \\
\hline & Meropenem & $\leq 0.06$ & $\leq 0.06$ & $\leq 0.06$ & 100 \\
\hline
\end{tabular}


TABLE 1 - CONTINUED

Ceftobiprole and doripenem in vitro activity against 2703 aerobic Gram-positive bacteria isolated from patients in Canadian hospitals in 2007

\begin{tabular}{|c|c|c|c|c|c|}
\hline Organism and phenotype (isolates, n) & Antimicrobial agent & MIC range, $\mu \mathrm{g} / \mathrm{mL}$ & $\mathrm{MIC}_{50}, \mu \mathrm{g} / \mathrm{mL}$ & $\mathrm{MIC}_{90}, \mu \mathrm{g} / \mathrm{mL}$ & $\%$ Susceptible \\
\hline \multirow[t]{7}{*}{ Enterococcus faecalis (161) } & Cefazolin & $0.5->128$ & 32 & 128 & NA \\
\hline & Cefepime & $\leq 1->128$ & 128 & 128 & NA \\
\hline & Ceftobiprole & $\leq 0.06->32$ & 0.5 & 1 & NA \\
\hline & Ceftriaxone & $\leq 0.25->256$ & $>256$ & $>256$ & NA \\
\hline & Doripenem & $\leq 0.06-32$ & 4 & 8 & NA \\
\hline & Ertapenem & $0.25->32$ & 8 & 16 & NA \\
\hline & Meropenem & $\leq 0.06->32$ & 4 & 8 & NA \\
\hline \multirow[t]{7}{*}{ Enterococcus faecium (60) } & Cefazolin & $32->128$ & $>128$ & $>128$ & NA \\
\hline & Cefepime & $2->128$ & $>128$ & $>128$ & NA \\
\hline & Ceftobiprole & $0.25-128$ & 128 & 128 & NA \\
\hline & Ceftriaxone & $0.5->256$ & $>256$ & $>256$ & NA \\
\hline & Doripenem & $2->32$ & $>32$ & $>32$ & NA \\
\hline & Ertapenem & $4->32$ & $>32$ & $>32$ & NA \\
\hline & Meropenem & $4->32$ & $>32$ & $>32$ & NA \\
\hline
\end{tabular}

${ }^{*}$ Ceftobiprole minimum inhibitory concentratrations (MICs) were interpreted using Health Canada-approved breakpoints (21); ${ }^{\dagger}$ Penicillin-susceptible, MIC $\leq 0.06 \mu$ g/mL; ${ }^{\ddagger}$ Penicillin-intermediate, MIC $0.12 \mu \mathrm{g} / \mathrm{mL}$ to $1 \mu \mathrm{g} / \mathrm{mL}$; ${ }^{\S}$ Penicillin-resistant, MIC $2 \mu \mathrm{g} / \mathrm{mL}$. MIC ${ }_{50 / 90}$ MICs required to inhibit 50\%/90\% of organisms; NA Not available

streptococci tested were susceptible to ceftobiprole (MIC $0.5 \mu \mathrm{g} / \mathrm{mL}$ or less); MIC interpretative breakpoints are not available for pneumococci. Ceftobiprole demonstrated lower $\mathrm{MIC}_{90} \mathrm{~s}$ than the other cephalosporins tested (cefazolin, cefepime, ceftriaxone) against MRSA, MRSE, methicillinsusceptible $S$ aureus, methicillin-susceptible $S$ epidermidis, penicillin-intermediate $S$ pneumoniae, penicillin-resistant S pneumoniae and Enterococcus faecalis.

Against Gram-negative bacilli, ceftobiprole demonstrated activity similar to that of cefepime (Table 2). Greater than 99\% of ESBL-negative E coli and K pneumoniae were susceptible to ceftobiprole (MIC $1 \mu \mathrm{g} / \mathrm{mL}$ or less); in contrast, $10 \%$ or less of isolates of ESBL-positive E coli and $K$ pneumoniae were susceptible to ceftobiprole. Against other genera/species of Enterobacteriaceae, susceptibility to ceftobiprole ranged from 80.7\% for Enterobacter cloacae to $99.2 \%$ for Proteus mirabilis. Ceftobiprole was less active against $P$ aeruginosa $\left(\mathrm{MIC}_{90} 32 \mu \mathrm{g} / \mathrm{mL}\right)$ and Stenotrophomonas maltophilia ( $\left.\mathrm{MIC}_{90} 128 \mu \mathrm{g} / \mathrm{mL}\right)$ than against Acinetobacter baumannii $\left(\mathrm{MIC}_{90} 2 \mu \mathrm{g} / \mathrm{mL}\right)$, Moraxella catarrhalis $\left(\mathrm{MIC}_{90} 0.5 \mu \mathrm{g} / \mathrm{mL}\right)$ and Haemophilus influenzae $\left(\mathrm{MIC}_{90} 0.12 \mu \mathrm{g} / \mathrm{mL}\right)$.

Doripenem $\mathrm{MIC}_{90} \mathrm{~s}$ were $0.5 \mu \mathrm{g} / \mathrm{mL}$ or less for all genera/ species of Enterobacteriaceae tested (Table 2). Doripenem was equally active against ESBL-positive and ESBL-negative isolates of $E$ coli and $K$ pneumoniae ( $\mathrm{MIC}_{90} \mathrm{~s} 0.5 \mu \mathrm{g} / \mathrm{mL}$ or less). Doripenem and meropenem were equally active against isolates of $P$ aeruginosa $\left(\mathrm{MIC}_{90} 8 \mu \mathrm{g} / \mathrm{mL}\right), \mathrm{M}$ catarrhalis $\left(\mathrm{MIC}_{90} 0.06 \mu \mathrm{g} / \mathrm{mL}\right.$ or less) and $\mathrm{H}$ influenzae $\left(\mathrm{MIC}_{90} 0.5 \mu \mathrm{g} / \mathrm{mL}\right)$. Doripenem was more active $\left(\mathrm{MIC}_{90} 0.5 \mathrm{\mu g} / \mathrm{mL}\right)$ than either meropenem $\left(\mathrm{MIC}_{90} 4 \mu \mathrm{g} / \mathrm{mL}\right)$ or ertapenem $\left(\mathrm{MIC}_{90} 8 \mu \mathrm{g} / \mathrm{mL}\right)$ against A baumannii. Doripenem demonstrated predictable activity against the Gram-positive pathogens tested with its activity being equally potent to that conferred by meropenem and ertapenem (Table 1).

\section{DISCUSSION}

Ceftobiprole is a broad-spectrum cephalosporin with demonstrated in vitro activity against Gram-positive and Gramnegative human pathogens, including MRSA and MRSE, as well as some species of anaerobic bacteria (2,13-18). The data presented in the current study confirm previously published ceftobiprole MIC results for the Gram-positive and Gramnegative pathogens tested (13-16). Importantly, all isolates of S aureus (MIC $4 \mu \mathrm{g} / \mathrm{mL}$ or less) and S pyogenes (MIC $0.5 \mu \mathrm{g} / \mathrm{mL}$ or less) tested in the current study were susceptible to ceftobiprole. Ceftobiprole also demonstrates more potent activity than ceftriaxone against penicillin-resistant S pneumoniae (19). Against Enterobacteriaceae and $P$ aeruginosa isolates, the potency of ceftobiprole was similar to that of cefepime (Table 2) (2). Ceftobiprole has been previously reported to be as potent as ceftazidime against $P$ aeruginosa (18).

As in vitro testing of ceftobiprole enters clinical laboratories, it will be crucial to ensure that laboratorians are aware not to automatically convert ceftobiprole MIC interpretations to resistant for isolates of MRSA as is done for every other betalactam (10). Ceftobiprole is distinct from all other beta-lactam agents because of its unique mechanism of action. Ceftobiprole demonstrates high affinity binding to penicillin-binding protein (PBP)2a of methicillin-resistant staphylococci, including MRSA $(16,20)$. For this reason, ceftobiprole is indicated to treat infections caused by MRSA $(12,15)$, and laboratories should report ceftobiprole MIC interpretations as they test and not apply an expert rule to the result as is done for all other beta-lactams when an isolate of $S$ aureus is identified as an MRSA. In addition to its high affinity binding to PBP2a in staphylococci, ceftobiprole also has high affinity for PBP2x in penicillin-resistant $S$ pneumoniae, and PBP2, PBP3 and other essential PBPs in methicillin-susceptible $S$ aureus, E coli and $P$ aeruginosa (20).

Like cefepime, ceftobiprole is stable to hydrolysis by many class A beta-lactamases, such as staphylococcal penicillinases, TEM-1, TEM-2, SHV-1 and class C beta-lactamases (ie, AmpC cephalosporinases produced by Gram-negative bacteria) $(16,21)$. Ceftobiprole is a weak inducer of AmpC betalactamase and a poor substrate for hydrolysis by AmpC beta-lactamase (15). In contrast, ceftobiprole is not stable to most ESBLs from the TEM, SHV and CTX-M families, to class A serine carbapenemases such as KPC or SME enzymes, 
TABLE 2

Ceftobiprole and doripenem in vitro activity against 3726 aerobic Gram-negative bacteria isolated from patients in Canadian hospitals in 2007

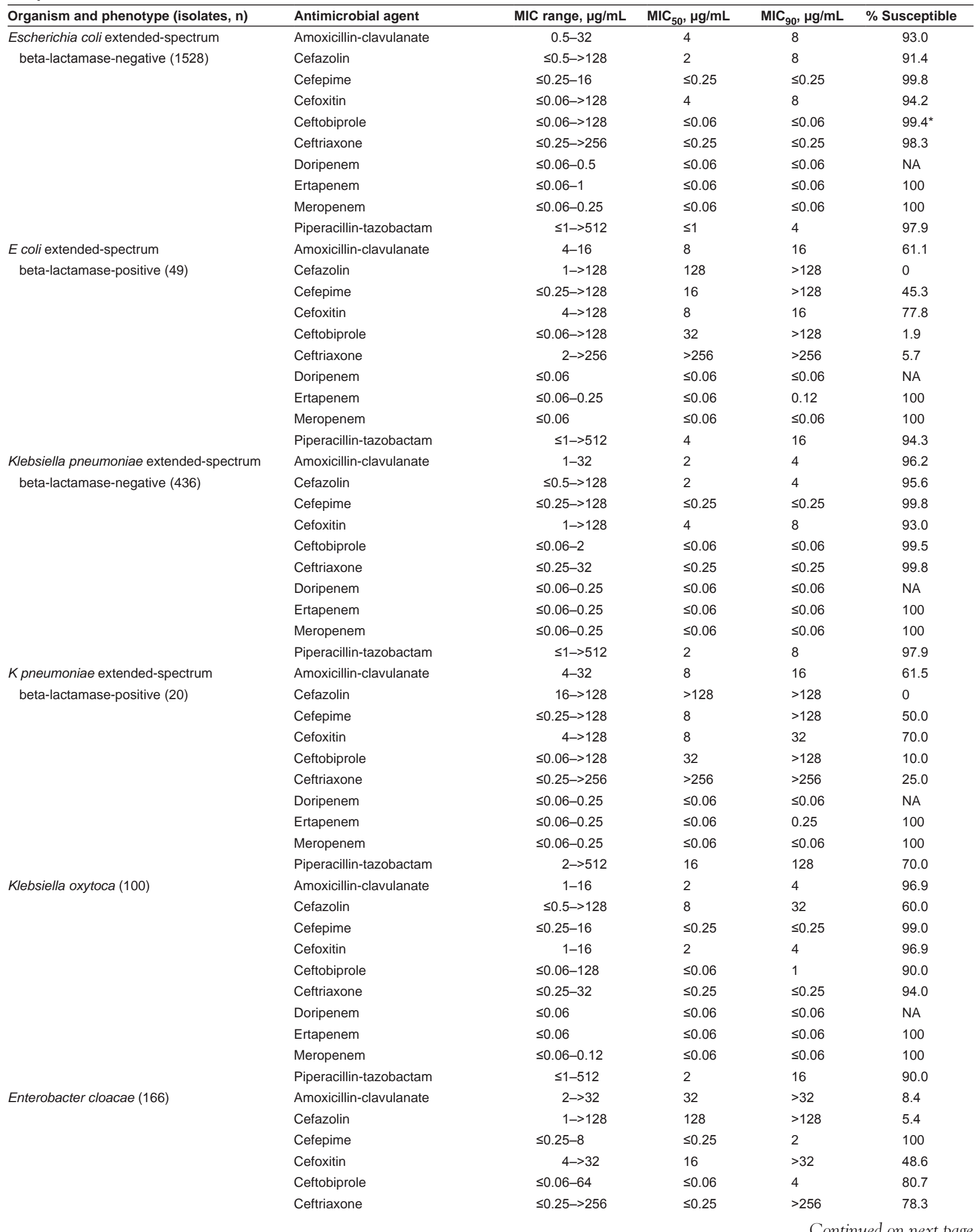


TABLE 2 - CONTINUED

Ceftobiprole and doripenem in vitro activity against 3726 aerobic Gram-negative bacteria isolated from patients in Canadian hospitals in 2007

\begin{tabular}{|c|c|c|c|c|c|}
\hline Organism and phenotype (isolates, $n$ ) & Antimicrobial agent & MIC range, $\mu \mathrm{g} / \mathrm{mL}$ & $\mathrm{MIC}_{50}, \mu \mathrm{g} / \mathrm{mL}$ & $\mathrm{MIC}_{90}, \mu \mathrm{g} / \mathrm{mL}$ & $\%$ Susceptible \\
\hline \multirow[t]{3}{*}{ Enterobacter cloacae (166) - continued } & Doripenem & $\leq 0.06-1$ & $\leq 0.06$ & $\leq 0.06$ & NA \\
\hline & Ertapenem & $\leq 0.06-2$ & $\leq 0.06$ & 0.5 & 100 \\
\hline & Meropenem & $\leq 0.06-0.5$ & $\leq 0.06$ & $\leq 0.06$ & 100 \\
\hline \multirow[t]{9}{*}{ Proteus mirabilis (119) } & Amoxicillin-clavulanate & $0.5-32$ & 1 & 4 & 97.1 \\
\hline & Cefazolin & $1-64$ & 8 & 16 & 86.6 \\
\hline & Cefepime & $\leq 0.25-2$ & $\leq 0.25$ & $\leq 0.25$ & 100 \\
\hline & Ceftobiprole & $\leq 0.06-2$ & $\leq 0.06$ & 0.12 & 99.2 \\
\hline & Ceftriaxone & $\leq 0.25-4$ & $\leq 0.25$ & $\leq 0.25$ & 100 \\
\hline & Doripenem & $\leq 0.06-1$ & $\leq 0.06$ & 0.5 & NA \\
\hline & Ertapenem & $\leq 0.06-0.12$ & $\leq 0.06$ & $\leq 0.06$ & 100 \\
\hline & Meropenem & $\leq 0.06-0.25$ & $\leq 0.06$ & $\leq 0.06$ & 100 \\
\hline & Piperacillin-tazobactam & $\leq 1-2$ & $\leq 1$ & $\leq 1$ & 100 \\
\hline \multirow{7}{*}{ Serratia marcescens (108) } & Cefoxitin & $4->32$ & 16 & $>32$ & 7.7 \\
\hline & Ceftobiprole & $\leq 0.06-8$ & $\leq 0.06$ & 0.5 & 95.3 \\
\hline & Ceftriaxone & $\leq 0.25->64$ & $\leq 0.25$ & 8 & 92.5 \\
\hline & Doripenem & $\leq 0.06-1$ & $\leq 0.06$ & 0.25 & NA \\
\hline & Ertapenem & $\leq 0.06-0.5$ & $\leq 0.06$ & $\leq 0.06$ & 100 \\
\hline & Meropenem & $\leq 0.06-2$ & $\leq 0.06$ & $\leq 0.06$ & 100 \\
\hline & Piperacillin-tazobactam & $\leq 1-128$ & 2 & 8 & 94.4 \\
\hline \multirow[t]{4}{*}{ Pseudomonas aeruginosa (633) } & Cefepime & $\leq 0.25->128$ & 8 & 32 & 67.4 \\
\hline & Ceftobiprole & $0.25->128$ & 4 & 32 & NA \\
\hline & Ceftriaxone & $\leq 0.25->256$ & 32 & 256 & 23.9 \\
\hline & Doripenem & $\leq 0.06->64$ & 0.5 & 8 & NA \\
\hline \multirow{3}{*}{ Stenotrophomonas maltophilia (107) } & Ertapenem & $0.12->32$ & $>32$ & $>32$ & NA \\
\hline & Meropenem & $\leq 0.06->64$ & $>64$ & $>64$ & NA \\
\hline & Piperacillin-tazobactam & $16->512$ & 256 & $>512$ & NA \\
\hline \multirow[t]{8}{*}{ Acinetobacter baumannii (25) } & Amoxicillin-clavulanate & $2->32$ & 8 & $>32$ & NA \\
\hline & Cefepime & $\leq 0.25->128$ & 4 & 16 & 84.0 \\
\hline & Ceftobiprole & $0.12-128$ & 1 & 2 & NA \\
\hline & Ceftriaxone & $4->256$ & 16 & 32 & 24.0 \\
\hline & Doripenem & $\leq 0.06-32$ & 0.25 & 0.5 & NA \\
\hline & Ertapenem & $2->32$ & 4 & 8 & NA \\
\hline & Meropenem & $\leq 0.06-32$ & 0.5 & 4 & 92.0 \\
\hline & Piperacillin-tazobactam & $\leq 1->512$ & 4 & $>512$ & 76.6 \\
\hline \multirow[t]{9}{*}{ Moraxella catarrhalis (93) } & Amoxicillin-clavulanate & $\leq 0.06-0.5$ & 0.12 & 0.25 & 100 \\
\hline & Cefazolin & $1->128$ & 128 & $>128$ & NA \\
\hline & Cefepime & $\leq 0.25-8$ & $\leq 0.25$ & 2 & NA \\
\hline & Ceftobiprole & $\leq 0.06-1$ & 0.12 & 0.5 & NA \\
\hline & Ceftriaxone & $\leq 0.25-1$ & $\leq 0.25$ & 1 & 100 \\
\hline & Doripenem & $\leq 0.06$ & $\leq 0.06$ & $\leq 0.06$ & NA \\
\hline & Ertapenem & $\leq 0.06-0.12$ & $\leq 0.06$ & $\leq 0.06$ & NA \\
\hline & Meropenem & $\leq 0.06$ & $\leq 0.06$ & $\leq 0.06$ & NA \\
\hline & Piperacillin-tazobactam & $\leq 1$ & $\leq 1$ & $\leq 1$ & NA \\
\hline
\end{tabular}




\begin{tabular}{|c|c|c|c|c|c|}
\hline Organism and phenotype (isolates, n) & Antimicrobial agent & MIC range, $\mu \mathrm{g} / \mathrm{mL}$ & $\mathrm{MIC}_{50}, \mu \mathrm{g} / \mathrm{mL}$ & $\mathrm{MIC}_{90}, \mu \mathrm{g} / \mathrm{mL}$ & $\%$ Susceptible \\
\hline \multirow[t]{8}{*}{ Haemophilus influenzae (342) } & Amoxicillin-clavulanate & $\leq 0.06-8$ & 0.5 & 1 & 99.7 \\
\hline & Cefepime & $\leq 0.25-2$ & $\leq 0.25$ & $\leq 0.25$ & 100 \\
\hline & Ceftobiprole & $\leq 0.06-2$ & $\leq 0.06$ & 0.12 & NA \\
\hline & Ceftriaxone & $\leq 0.06->4$ & $\leq 0.06$ & $\leq 0.06$ & 99.7 \\
\hline & Doripenem & $\leq 0.06-2$ & $\leq 0.06$ & 0.5 & NA \\
\hline & Ertapenem & $\leq 0.03->4$ & $\leq 0.03$ & 0.12 & 99.7 \\
\hline & Meropenem & $\leq 0.06-2$ & $\leq 0.06$ & 0.12 & 99.7 \\
\hline & Piperacillin-tazobactam & $\leq 1-2$ & $\leq 1$ & $\leq 1$ & 99.7 \\
\hline
\end{tabular}

${ }^{*}$ Ceftobiprole minimum inhibitory concentrations (MICs) for Enterobacteriaceae interpreted using Health Canada-approved breakpoints (21). MIC ${ }_{50 / 90}$ MICs required to inhibit $50 \% / 90 \%$ of organisms; NA Not available

to class B metallo-beta-lactamases including members of the IMP or VIM families, or to class D enzymes (eg, OXA1 to OXA-11) (16,21). Ceftobiprole is also hydrolyzed by betalactamases from anaerobic bacteria (16). Like cefotaxime, ceftriaxone, ceftazidime and cefepime, ceftobiprole demonstrates limited activity against anaerobes such as Bacteroides fragilis and non-fragilis Bacteroides species (16).

The pharmacodynamic profile of ceftobiprole is similar to that of other compounds within the cephalosporin class (22). Ceftobiprole exhibits concentration-independent killing, and animal infection models have established the time the free drug concentration exceeds the MIC as the principal pharmacodynamic parameter predictive of efficacy (22). In single-step and serial passage in vitro and in vivo resistance development studies, ceftobiprole demonstrated a low propensity to select for resistant subpopulations $(16,23,24)$.

The current study confirmed previously published results that reported that doripenem was a broad-spectrum carbapenem with in vitro activity against Gram-positive and Gram-negative pathogens (5-7). Some previous studies have shown doripenem to be more active than other carbapenems against $P$ aeruginosa $(6,7)$; however, this was not observed in the current study. Doripenem has been reported to display the favourable characteristics of other carbapenems, and appears to offer certain advantages in terms of potency, spectrum and beta-lactamase stability when compared with some carbapenems used currently to treat nosocomial infections (5). Carbapenems have broad-spectrum activity against most Grampositive and Gram-negative pathogens, and their enhanced stability to most Ambler class A, C and D beta-lactamases (6). Carbapenems have generally been reserved for the most severe infections, or for infections caused by organisms known to be resistant to other available beta-lactams, especially those with an extended spectrum of activity. Doripenem is also not subject to inactivation by renal dehydropeptidases, a characteristic of imipenem (6).

\section{CONCLUSIONS}

The current study demonstrated both ceftobiprole and doripenem to be broad-spectrum antibacterial agents. In the past, empirical antimicrobial coverage of both Gram-positive and Gram-negative infections has generally necessitated the use of at least two antimicrobial agents. Several qualities make ceftobiprole uniquely suited for early empiric use of infections likely to be caused by Gram-positive organisms and mixed Grampositive and Gram-negative organisms (22). Ceftobiprole represents an effective alternative therapy for complicated skin and skin structure infections, including those caused by MRSA and many Gram-negative aerobic and facultative bacilli. Ceftobiprole has an enhanced anti-Gram-positive spectrum, including MRSA, while maintaining broad antiGram-negative activity, and possesses stability to many of the beta-lactamases produced by both Gram-positive and Gram-negative pathogens (13). All isolates of MRSA tested were susceptible to ceftobiprole (MIC $4 \mu \mathrm{g} / \mathrm{mL}$ or less), differentiating it from any other currently marketed beta-lactam. Doripenem also demonstrated potent activity $\left(\mathrm{MIC}_{90} 0.5 \mu \mathrm{g} / \mathrm{mL}\right.$ or less) against all isolates of Enterobacteriaceae tested, including ESBL-producing E coli and $K$ pneumoniae, and as potent activity as meropenem $\left(\mathrm{MIC}_{90} 8 \mu \mathrm{g} / \mathrm{mL}\right)$ against $P$ aeruginosa.

ACKNOWLEDGEMENTS: Funding for the CANWARD 2007 study was provided by Affinium, Astellas Pharma Canada, Janssen Ortho, Oryx, Pfizer Canada, TaiGen, Targanta, Wyeth, University of Manitoba, Winnipeg Health Sciences Centre and the National Microbiology Laboratory-Health Canada. The authors would like to thank Nancy Laing, Barb Weshnoweski, Ravi Vashisht, Lisa Bittner and Haley Butcher for their technical assistance. The authors would also like to thank the investigators and laboratory site staff at each medical centre that participated in the CANWARD 2007 study. The investigators of the CANWARD 2007 study are listed in another paper in the present supplement by Zhanel et al (25). CANWARD data are also displayed at www. can-r.ca, the official Web site of the Canadian Antimicrobial Resistance Alliance.

\section{REFERENCES}

1. Lipsky BA, Weigelt JA, Gupta V, et al. Skin, soft tissue, bone, and joint infections in hospitalized patients: Epidemiology and microbiological, clinical, and economic outcomes. Infect Control Hosp Epidemiolol 2007;28:1290-8.

2. Amsler KM, Davies TA, Shang W, et al. In vitro activity of ceftobiprole against pathogens from two phase 3 clinical trials of complicated skin and skin structure infections. Antimicrob Agents Chemother 2008;52:3418-23.

3. Moet GJ, Jones RN, Biedenbach DJ, et al. Contemporary causes of skin and soft tissue infections in North America, Latin America, and Europe: Report from the SENTRY Antimicrobial Surveillance Program (1998-2004). Diagn Microbiol Infect Dis 2007;57:7-13. 
4. Styers D, Sheehan DJ, Hogan P, Sahm DF. Laboratory-based surveillance of current antimicrobial resistance patterns and trends among Staphylococcus aureus: 2005 status in the United States. Ann Clin Microbiol Antimicrob 2006;5:2.

5. Fritsche TR, Stilwell MG, Jones RN. Antimicrobial activity of doripenem (S-4661): A global surveillance report (2003). Clin Microbiol Infect 2005;11:974-84.

6. Zhanel GG, Wiebe R, Dilay L, et al. Comparative review of carbapenems. Drugs 2007;67:1027-52.

7. Goldstein EJC, Citron DM, Merriam CV, et al. In vitro activities of doripenem and six comparator drugs against 423 aerobic and anaerobic bacterial isolates from infected diabetic foot wounds. Antimicrob Agents Chemother 2008;52:761-6.

8. Zhanel GG, DeCorby MR, Nichol KA, et al. Antimicrobial susceptibility of 6685 organisms isolated from Canadian hospitals: CANWARD 2007. Can J Infect Dis Med Microbiol 2009;20(Suppl A):20A-30A.

9. Clinical and Laboratory Standards Institute. Methods for dilution antimicrobial susceptibility tests for bacteria that grow aerobically; approved standard-seventh edition. Clinical and Laboratory Standards Institute, Wayne, PA. 2006.

10. Clinical and Laboratory Standards Institute. Performance standards for antimicrobial susceptibility testing: 17th informational supplement, document M100-S17. Clinical and Laboratory Standards Institute, Wayne, PA. 2007.

11. Clinical and Laboratory Standards Institute. Methods for antimicrobial dilution and disk susceptibility testing of infrequently isolated or fastidious bacteria; approved guideline. M45-A, vol. 26, no. 19. Clinical and Laboratory Standards Institute, Wayne, PA. 2006.

12. Janssen-Ortho Inc. Zeftera product monograph, June 26, 2008.

13. Bush K, Heep M, Macielag MJ, Noel GL. Anti-MRSA beta-lactams in development with a focus on ceftobiprole: the first anti-MRSA beta-lactam to demonstrate clinical efficacy. Exp Opin Invest Drug 2007;16:419-29.

14. Noel GL. Clinical profile of ceftobiprole, a novel beta-lactam with activity against methicillin-resistant Staphylococcus aureus. Clin Microbiol Infect 2007;13(Suppl 2):25-9.

15. Jones ME. In vitro profile of a new beta-lactam ceftobiprole with activity against methicillin-resistant Staphylococcus aureus. Clin Microbiol Infect 2007;13(Suppl 2):17-24.
16. Zhanel GG, Lam A, Schweizer F, et al. Ceftobiprole: a review of a broad-spectrum and anti-MRSA cephalosporin. Am J Clin Dermatol 2008;9:245-54.

17. Goldstein EJC, Citron DM, Merriam CV, et al. In vitro activity of ceftobiprole against aerobic and anaerobic strains isolated from diabetic foot infections. Antimicrob Agents Chemother 2006;50:3959-62.

18. Fritsche TR, Sader HS, Jones RN. Antimicrobial activity of ceftobiprole, a novel anti-methicillin-resistant Staphylococcus aureus cephalosporin, tested against contemporary pathogens: Results from the SENTRY antimicrobial surveillance program (2005-2006). Diagn Microbiol Infect Dis 2008;61:86-95.

19. Davies TA, Shang W, Bush K. Activities of ceftobiprole and other $\beta$-lactams against Streptococcus pneumoniae clinical isolates from the United States with defined substitutions in penicillin binding proteins PBP 1a, PBP 2b, and PBP 2x. Antimicrob Agents Chemother 2006;50:2530-2.

20. Davies TA, Page MGP, Shang W, et al. Binding of ceftobiprole and comparators to the penicillin binding proteins of Escherichia coli, Pseudomonas aeruginosa, Staphylococcus aureus, and Streptococcus pneumoniae. Antimicrob Agents Chemother 2007;51:2621-4.

21. Queenan AM, Shang W, Kania, et al. Interactions of ceftobiprole with $\beta$-lactamases from molecular classes A to D. Antimicrob Agents Chemother 2007;51:3089-95.

22. Lodise TP, Patel N, Renaud-Mutart A, et al. Pharmacokinetic and pharmacodynamic profile of ceftobiprole. Diagn Microbiol Infect Dis 2008;61:96-102.

23. Bogdanovich T, Ednie LM, Shapiro S, Appelbaum PC. Antistaphylococcal activity of ceftobiprole, a new broad-spectrum cephalosporin. Antimicrob Agents Chemother 2005;49:4210-9.

24. Vaudaux P, Gjinovci, Bento M, et al. Intensive therapy with ceftobiprole medocaril of experimental foreign-body infection by methicillin-resistant Staphylococcus aureus. Antimicrob Agents Chemother 2005;49:3789-93.

25. Zhanel GG, Karlowsky JA, DeCorby M, et al. Prevalence of antimicrobial-resistant pathogens in Canadian hospitals: Results of the Canadian Ward Surveillance Study (CANWARD 2007). Can J Infect Dis Med Microbiol 2009;20(Suppl A):9A-19A 


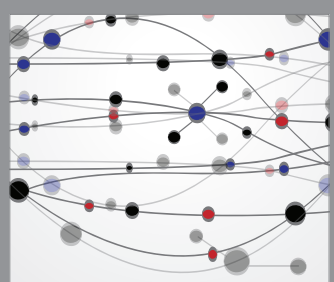

The Scientific World Journal
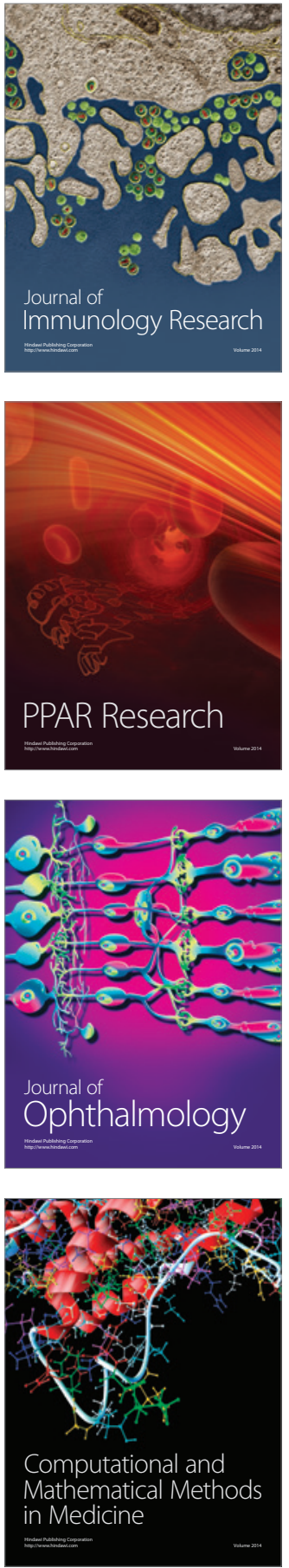

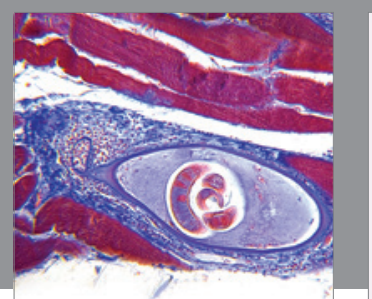

Gastroenterology Research and Practice

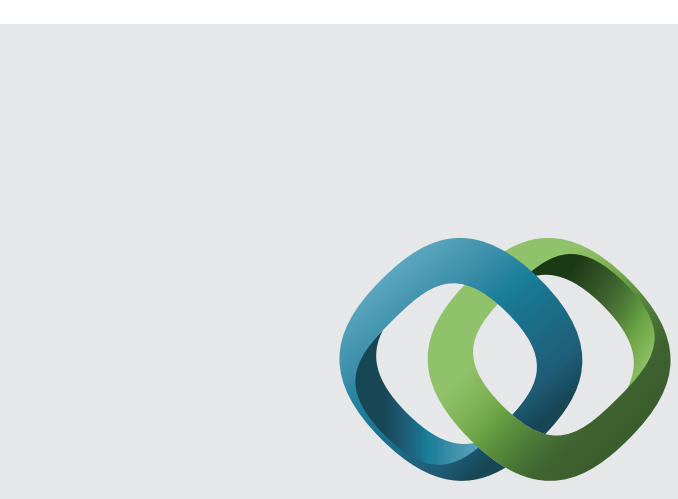

\section{Hindawi}

Submit your manuscripts at

http://www.hindawi.com
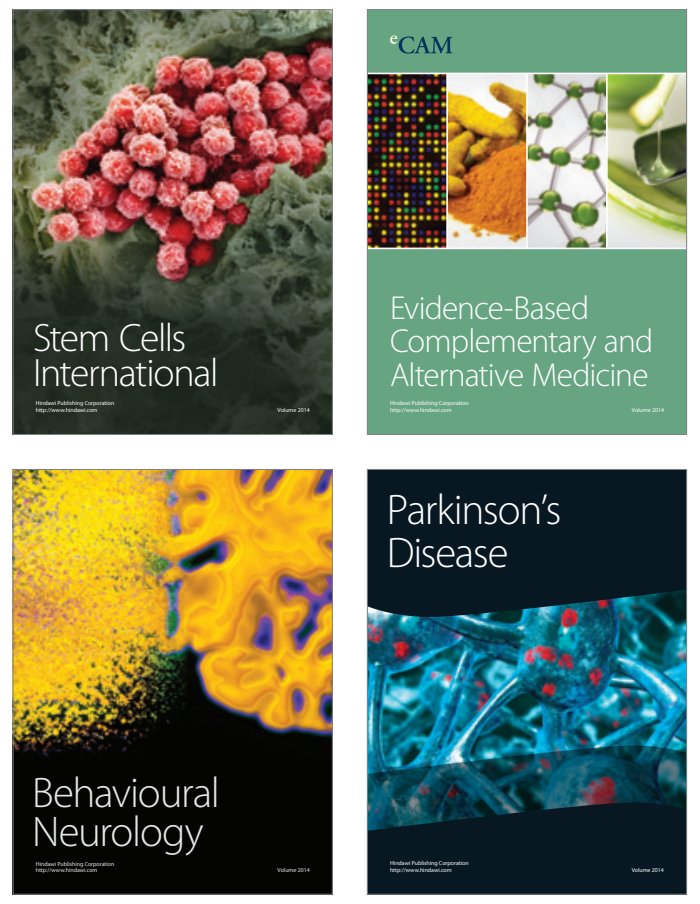
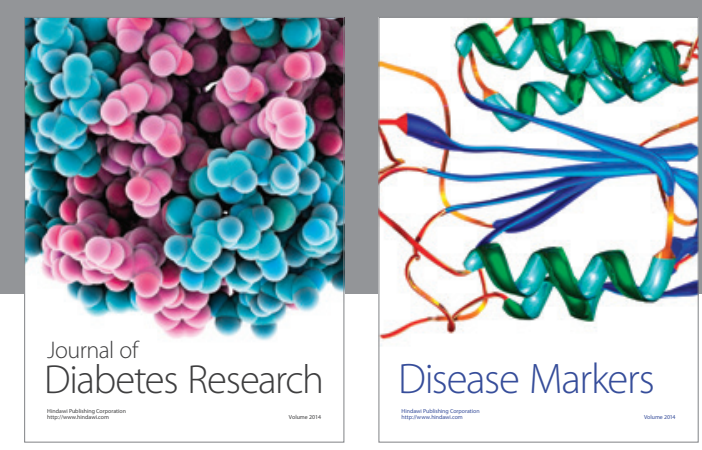

Disease Markers
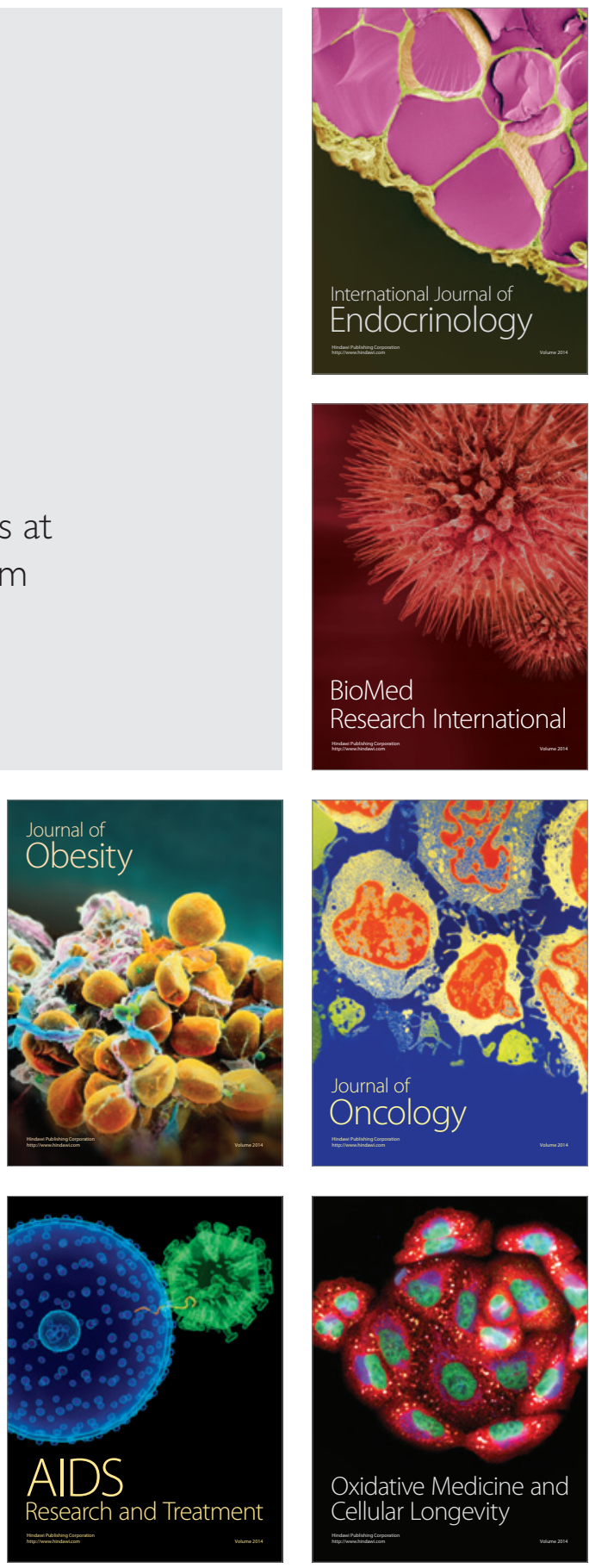